\author{
Leszek Mateja ${ }^{1}$ \\ Uniwersytet Papieski Jana Pawła II w Krakowie
}

\title{
Ewangeliczne etapy rozwoju postawy miłosierdzia w świetle wybranych fragmentów pism ojców Kościoła
}

Postawy miłosierdzia opisane w ewangeliach i pismach ojców Kościoła nie są rzeczywistością statyczną, ale dynamiczną, podobnie jak sama doktryna miłosierdzia, która rozwijała się co najmniej na przestrzeni pierwszych trzech wieków chrześcijaństwa². W tym przyczynku pragnę przedstawić zarys ewangelicznych etapów rozwoju postawy miłosierdzia w wymiarze materialnym w świetle wybranych fragmentów pism ojców Kościoła. W celu ukazania procesu rozwoju miłosierdzia człowieka wykorzystam metodę inicjacyjnego odczytania tekstów Nowego Testamentu ${ }^{3}$.

1 Ks. dr Leszek Mateja - absolwent patrologii na Wydziale Teologicznym Papieskiej Akademii Teologicznej, proboszcz parafii Narodzenia Najświętszej Marii Panny w Rusocicach w archidiecezji krakowskiej. Autor programu duszpasterskiego Droga ewangelicznego wtajemniczenia, którego pierwszy etap jest opisany w książce: Bóg mówi do ciebie: Poznaj Mnie. Nawrócenie i towarzyszenie Jezusowi, Kraków 2016. Prezentowany artykuł jest natomiast syntezą prawd rozwiniętych w kolejnej książce z tego cyklu: Bóg mówi do ciebie: zaufaj Mi. Biblijna szkoła ufności i miłosierdzia, Kraków 2017, s. 150-249. E-mail: leszekmateja@poczta.onet.pl.

2 Por. L. Mateja, Oblicza miłosierdzia. Historyczne uwarunkowania rozwoju doktryny o miłosierdziu. Studium dzieł Tertuliana i świętego Cypriana, Kraków 2003, s. 274-278.

3 Por. B. Górka, Podejście inicjacyjne do Ewangelii Jana, w: Hermeneutyka inicjacji wczesnochrześcijańskiej, Kraków 2007, s. 13-26. B. Górka ukazał również ewolucyjny charakter chrześ- 
Dzięki tej metodzie można wyodrębnić kolejne etapy rozwoju postawy miłosierdzia człowieka w miarę wzrostu jego wiary w Jezusa. W Kościele starożytnym ten rozwój wiary i odpowiadającej jej moralności przebiegał w ramach inicjacji przedchrzcielnej na trzech etapach, które Klemens Aleksandryjski definiuje jako „zachętę, prekatechumenat i katechumenat”. Kierując się tak wyrażoną tradycją Kościoła starożytnego, podejmę próbę opisania postaw miłosierdzia, które odzwierciedlają egzystencjalną wiarę wtajemniczanych w osobę Jezusa na poszczególnych etapach inicjacji. Tymi postawami są: filantropia, miłosierdzie czynione ze względu na Boga, doskonalenie wrażliwości, wolność od posiadania dóbr ziemskich, miłość nieprzyjaciół i miłość wzajemna.

\section{Filantropia}

Szukając tekstów Ewangelii dotyczących miłosierdzia człowieka na najbardziej podstawowym poziomie, należy sięgnąć do tych, w których jest wezwanie do posługi miłosierdzia w celu pozyskania sobie przychylności drugiego człowieka. Taką postawę możemy nazwać filantropią ${ }^{5}$. Charakteryzowała ona tych, którzy w starożytności byli na etapie wstępnym inicjacji chrzcielnej, zwanej przez Klemensa Aleksandryjskiego z a ch ęt ą. Jezus wzywa do takich czynów, kiedy mówi: „Pozyskujcie sobie przyjaciół niegodziwą mamoną, aby gdy wszystko się skończy, przyjęto was do wiecznych przybytków" (Łk 16, 9). Celem takiej postawy nie jest bezpośrednio zdobycie sobie przychylności Boga, ale ludzi. Jednak zdobywając sobie w ten sposób przyjaciół wśród ludzi, człowiek otrzymuję nadzieję życia wiecznego.

W cytowanym fragmencie pojawia się kontrowersyjne stwierdzenie: „niegodziwa mamona”, które można również przetłumaczyć jako „mamo-

cijańskiej moralności w artykule: Ewolucyjny charakter chrześcijańskiej moralności, w: B. Górka, Chrześcijaństwo pierwotne jako system religijny, Kraków 2011, s. 17-34.

4 S. Łucarz, Disciplina arcani w „Kobiercach” Klemensa Aleksandryjskiego, w: Disciplina arcani w chrześcijaństwie, red. W. Gajewski, B. Górka, Kraków 2015, s. 76.

5 Por. J. Machniak, Miłosierdzie a filantropia, w: Wspótczesne oblicza miłosierdzia, red. L. Mateja, Kraków 2007, s. 73. 
na niesprawiedliwości”. Klemens Aleksandryjski tak komentował te słowa: „W słowach tych wskazuje Chrystus na to, że każde posiadanie jest z natury niesprawiedliwe, jeśli ktoś pragnie posiadać coś tylko dla siebie, jako swoją własność, a nie dzieli się swym mieniem z potrzebującymi jako dobrem wspólnym”. Zdaniem Klemensa „każde posiadanie”, czyli „mamona”, ,jest z natury niesprawiedliwe”, jeśli posiadający nie dzieli się z potrzebującymi.

Następne słowa Jezusa z tej ewangelicznej perykopy (por. Łk 16, 10-11) są wezwaniem do uczciwego zarządzania mamoną, czyli do mądrego korzystania z własnych dóbr materialnych. Aramejskie słowo mamona oznacza między innymi ostoję, czyli majątek, który jest oparciem dla człowieka, dającym mu gwarancję bezpieczeństwa materialnego. Wierność w zarządzaniu takimi dobrami oznacza troskę o to, aby to materialne oparcie było stabilne, by dawało poczucie bezpieczeństwa dla danego człowieka i jego rodziny.Jednak wcześniejsze słowa Jezusa o pozyskiwaniu sobie przyjaciół niegodziwą mamoną sugerują, że mamona powinna być oparciem materialnym dla danego człowieka, a także dla innych, poprzez jego miłosierdzie. Na tym etapie rozwoju postawy miłosierdzia człowiek jest wezwany, aby dzielił się tym, co nie uszczupla jego bezpieczeństwa materialnego, a staje się ostoją materialną dla innych, którzy do tej pory jej nie mieli.

Słowa Jezusa o wiernym zarządzaniu cudzym dobrem (por. Łk 16, 12) należy rozumieć jako wezwanie do uczciwego wypełniania obowiązków w swojej pracy. Ma to być postawa przeciwna do tej, którą zaprezentował nieuczciwy zarządca (por. Łk 16, 1-8). Jest to czas pozyskiwania nie tylko przychylności ludzi, ale także i łaskawości Boga, choć wielu może sobie tego jeszcze nie uświadamiać. Jednak jeśli ktoś przestaje służyć mamonie, na horyzoncie ukazuje mu się nowy Pan:Bóg. Można mówić tu o religijności na płaszczyźnie naturalnej, dostępnej każdemu człowiekowi.

Innym tekstem Ewangelii, który ukazuje postawę filantropii, jest Mateuszowy opis sądu ostatecznego (por. Mt 25, 31-46). Należy zwrócić uwagę na to, iż wszyscy, którzy podjęli uczynki miłosierdzia, nagro-

6 Clemens Alexandrinus, Quis dives salvetur?, 31, 8-9, Paris 2011, s. 182-184 (Sources Chretiennes, 537), przekł. pol.: Klemens Aleksandryjski, Czy człowiek bogaty może być zbawiony, tłum. J. Czuj, Warszawa 1953, s. 39. 
dzone przez Syna Człowieczego, wykonali je nie ze względu na Boga, ale ze względu na dobro człowieka. Poprzez czyny miłosierdzia pozyskiwali sobie przyjaciół wśród ludzi, a Jezus każdy tego typu uczynek odniósł do siebie, podobnie jak i postawę braku miłosierdzia. Ci, którzy zyskiwali sobie przyjaźń wśród ludzi poprzez okazywanie im miłosierdzia, zyskali przyjaźń Chrystusa, choć o to bezpośrednio nie zabiegali i nawet nie mieli takiej świadomości, stąd ich zdziwienie wyrażone w pytaniu: „Panie, kiedy?" (Mt 25, 37).

Orygenes, komentując rozpatrywany fragment Ewangelii, pisze:

Jeśli więc chodzi o prosty tekst, ani ci, co stoją „po prawej stronie”, nie spotykają się z pochwałą, ani nie zostają wezwani do „przygotowanego królestwa” z innej przyczyny, jak tylko dla samej ich ludzkości, ani ci, co są „po lewej stronie", z innej przyczyny nie spotkają się z naganą i wysłani zostają w ogień, jak tylko dla ich nieludzkości .

Orygenes uważa, że ci, których Syn Człowieczy postawił po swej prawej stronie, zostali nagrodzeni za postawę ludzkości (humanitatem), a ci po lewej zostali ukarani za postawę nieludzkości (inhumanitatem). Autor zatem mówi o podstawowych postawach człowieka w wymiarze miłosierdzia, które są charakterystyczne dla natury ludzkiej, nazwanych przez nas filantropią.

Jak łatwo zauważyć, uczynki miłosierdzia co do ciała mają swe źródło w tym fragmencie Ewangelii, zatem sytuują się jako podstawowa forma miłosierdzia ludzkiego, którą może spełnić każdy człowiek, także ten, który nie ma żadnej relacji z Bogiem, bowiem źródłem tej postawy jest miłość do człowieka.

\section{Miłosierdzie czynione ze względu na Boga}

Drugim etapem rozwoju postawy miłosierdzia są takież czyny podejmowane ze względu na Boga. Do takiej postawy wzywał Jan Chrzciciel, aby

7 Origenes, Commentariorum in Matthaeum series II, 70, 16-20, Leipzig 1933, s. 164 (Griechischen Christlichen Schriftsteller, 38), przekł. pol.: Orygenes, Komentarz do Ewangelii św. Mateusza, cz. 2, tłum. K. Agustyniak, Kraków 2002, s. 125 (Źródła Myśli Teologicznej, 25). 
w ten sposób przygotować się na spotkanie z nadchodzącym Mesjaszem (por. Łk 3, 3-14). Na pytanie tłumów: jak to uczynić, odpowiada: „Kto ma dwie suknie, niech się podzieli z tym, który nie ma; a kto ma żywność, niech tak samo czyni" (Łk 3,11). Prorok wyraźnie wzywa tu do czynów miłosierdzia. Natomiast na szczegółowe pytania celników i żołnierzy o to, co oni mają czynić, odpowiada, iż powinni wykonywać swoje zadania, nie wyrządzając innym krzywdy, czyli podejmować działania w oparciu o zasady sprawiedliwości.

Ambroży, biskup Mediolanu, komentując ten fragment Ewangelii, twierdzi, iż pouczenia związane z przestrzeganiem zasad sprawiedliwości dotyczą poszczególnych stanów, natomiast „miłosierdzie do wszystkich się odnosi; jest więc ogólnym nakazem, obowiązuje wszystkich, osoby każdego wieku. Nie jest od tego wykluczony celnik, żołnierz, rolnik, mieszczanin bogaty i ubogi. Wszyscy wspólnie są upomnieni, aby wspierali takiego, który nie posiada. Miłosierdzie bowiem jest pełnią cnót; toteż od wszystkich wymaga, aby tę cnotę doskonale pełnili; aby nie oszczędzali swej odzieży ani swych pokarmów. Jednakże w praktykowaniu miłosierdzia w miarę możności należy zachować odpowiedni umiar; nie ma ktoś wszystkiego sobie odmawiać, lecz tym, co ma, z ubogim się dzielić"8.

Biskup Mediolanu uważa, że miłosierdzie wyrażające się we wspieraniu ubogich jest ogólnym nakazem, który obowiązuje wszystkich ludzi. Nazywając miłosierdzie „pełnią cnót”, podkreślił, że jest to cnota uniwersalna i jako taka ma być przez wszystkich spełniana. Jednakże zaznacza, aby posługiwać się nią roztropnie w powiązaniu z cnotą umiaru, podkreślając ścisły związek miłosierdzia ze sprawiedliwością. Tak ujęte miłosierdzie należy w wymiarze inicjacyjnym odnieść do etapu prekatechumenatu, obowiązuje ono bowiem wszystkich tych, którzy żyją moralnością Tory i proroków, do której odwoływał się Jan Chrzciciel. Ten etap inicjacji dotyczył zarówno Żydów, jak i przedstawicieli innych narodów, przygotowujących się do przyjęcia chrztu. Można go również nazwać czasem nawrócenia, nawiązując do chrztu Janowego jako „chrztu nawrócenia” (Dz 19, 4).

8 Ambrosius, Expositio Evangelii secundum Lucam, 2, 77, Turnholti 1957, s. 64 (Corpus Cristianorum Series Latina, 14), przekł. pol.: Ambroży, Wykład Ewangelii według św. Łukasza, tłum. W. Szołdrski, Warszawa 1977, s. 84 (Pisma Starochrześcijańskich Pisarzy, 16). 


\section{Doskonalenie wrażliwości}

Trzecim etapem rozwoju postawy miłosierdzia jest doskonalenie wrażliwości, którą najlepiej przedstawia przypowieść o miłosiernym Samarytaninie (por. Łk 10, 30-37). Ewangelista Łukasz ukazuje człowieka na „pół umarłego” (Łk 10, 30), którego okradli i pobili zbójcy, a kiedy przyszedł na to miejsce Samarytanin, „gdy go zobaczył, wzruszył się głęboko" (Łk 10, 33). W tekście greckim pojawia się tu słowo esplanchnisthe, które podkreśla rolę uczuć w akcie miłosierdzia. W jakiejś mierze odpowiada ono słowu hebrajskiemu rahamim, które wiąże się z łonem matczynym, symbolizującym najgłębsze uczucia matki ${ }^{9}$.

Jeśli spojrzymy na teksty Ewangelii, w których jest mowa o miłosiernej postawie Jezusa, wszędzie tam znajdziemy różne formy słowa splanchna (Mt 9, 36; 15, 32; Mk 6, 34; 8, 2; Łk 7, 13) ${ }^{10}$. Jak stwierdza Józef Kudasiewicz, wszystkie te teksty mówią o ludzkim miłosierdziu Jezusa i jednocześnie charakteryzują Go jako Mesjasza, w którym jest obecne i działa miłosierdzie Boga ${ }^{11}$. Słowo esplanchnisthe jest użyte nie tylko w przypowieści o miłosiernym Samarytaninie (por. Łk 10,33), ale także w przypowieści o miłosiernym ojcu (por. Łk 15, 20). Natomiast inna forma tego słowa: splanchnistheis znajduje się w przypowieści o nielitościwym dłużni$\mathrm{ku}(\mathrm{Mt} 18,27)$. Tylko w tych trzech wymienionych fragmentach Nowego Testamentu występuje to słowo w kontekście miłosierdzia ludzi. Dlatego można uznać, że postawa wrażliwości miłosierdzia jest charakterystyczna dla tych, którzy w procesie rozwoju swej wiary pragną zjednoczyć się z Jezusem jako Mesjaszem. Odnosząc to doświadczenie do procesu inicjacji przedchrzcielnej w starożytnym Kościele, możemy mówić tu o etapie katechumenalnym.

Do tego etapu rozwoju miłosierdzia człowieka, który jest związany z doskonaleniem wrażliwości wobec cierpienia ludzi, nawiązuje Augustyn z Hippony, gdy pisze:

9 Por. K. Romaniuk, Biblijny traktat o miłosierdziu, Ząbki 1994, s. 10.

10 Analizę tych fragmentów pod kątem miłosierdzia Jezusa podjąłem w książce Oblicza miłosierdzia..., dz. cyt., s. 84-87.

11 Por. J. Kudasiewicz, Miłosierdzie w słowach i czynach Jezusa, w: Dives in misericordia. Tekst i komentarz, Kraków 1981, s. 110. 
Czymże jest bowiem miłosierdzie, jak nie pewnym w sercu naszym współczuciem czyjegoś nieszczęścia, które nas pobudza do spieszenia z pomocą, o ile to jest w naszych siłach. A takie poruszenie duszy jest poddane rozumowi, kiedy miłosierdzie tak się udziela, że sprawiedliwość pozostaje nienaruszona czy to wtedy, gdy ubogiego wspieramy, czy gdy pokutującemu przebaczamy ${ }^{12}$.

Cytowany fragment można uznać za definicję miłosierdzia, która wiąże się z przesłaniem przypowieści o miłosiernym Samarytaninie (por. Łk 10, 30-37), dlatego krótko porównamy oba teksty. Augustyn twierdzi, że akt miłosierdzia rozpoczyna się na płaszczyźnie uczuć człowieka, wówczas gdy ten spostrzega nieszczęście drugiego. Tę prawdę ilustruje postawa miłosiernego Samarytanina, który „wzruszył się głęboko” (Łk 10, 33). Następnie biskup Hippony sygnalizuje, że uczucia pobudzają człowieka, aby spieszył z pomocą potrzebującym, co zademonstrował Samarytanin, podchodząc do pobitego i opatrując mu rany (por. Łk 10, 34). Według Augustyna udzielenie pomocy powinno być na miarę możliwości tego, który okazuje miłosierdzie. Samarytanin wyraził to poprzez poświęcenie określonej ilości czasu i pieniędzy (por. Łk 10, 35). Najbardziej charakterystycznym elementem, który wiąże definicję miłosierdzia podaną przez Augustyna z przypowieścią o miłosiernym Samarytaninie, jest aspekt uczuć w kontekście postawy miłosierdzia. Jak już wspomnieliśmy, w tekście greckim omawianego fragmentu Ewangelii występuje tu słowo esplanchnisthe, które mówi o miłosierdziu na płaszczyźnie uczuciowej. Dlatego nawiązując do wniosków, które zostały sformułowane przy porównaniu ewangelicznych tekstów, w których znajduje się słowo splanchna, można uznać, że definicja miłosierdzia autorstwa Augustyna dotyczy postawy miłosierdzia charakterystycznej dla katechumena.

\section{Wolność od posiadania dóbr ziemskich}

Czwartym etapem rozwoju postawy miłosierdzia jest wolność od posiadania dóbr ziemskich. Jak wykażemy, charakteryzuje on tych, któ-

12 Augustinus Hipponesis, De civitate Dei, 9, 5, 17-21, Turnholti 1955, s. 254 (Corpus Cristianorum Series Latina, 47), przekł. pol.: Augustyn z Hippony, O Państwie Bożym, tłum. W. Kubiak, Kęty 1998, s. 334. 
rzy kończą katechumenat. Ewangelicznym tekstem mówiącym o tym etapie wtajemniczenia jest spotkanie Jezusa $\mathrm{z}$ bogatym młodzieńcem (por. Mt 19, 16-22). Jednak, aby odczytać to wydarzenie w kluczu inicjacyjnym, należy wpierw zatrzymać się nad poprzedzającym je, czyli tym, kiedy to przynoszono do Jezusa dzieci (por. Mt 19, 13-15).

Orygenes, komentując to wydarzenie, pisze:

Dziećmi zaś należy nazywać tych, którzy są jeszcze cieleśni w Chrystusie, są jak niemowlęta. Wiedząc, że takimi są Koryntianie, Paweł mówi: „A ja nie mogłem przemawiać do was jako do ludzi duchowych, lecz jako do cielesnych, jak do niemowląt w Chrystusie”. Takie to „dzieci” zostały przyniesione i „wtedy”, i zawsze są przynoszone Jezusowi ${ }^{13}$.

Według Orygenesa dzieci w tym wydarzeniu symbolizują ludzi cielesnych. O tym etapie w rozwoju wewnętrznym pisze św. Paweł (por. Rz 7, 14-25), gdy ukazuje walkę duchową człowieka, który jest już uwolniony z grzechów personalnych, ale jeszcze nie z grzechu natury, czyli z grzechu pierworodnego. Ten stan dziecięctwa Bożego jest doświadczeniem katechumenów, którzy doskonalą swoją wiarę w Jezusa jako Mesjasza. Tak o nich pisze św. Jan: „Każdy, kto wierzy, że Jezus jest Mesjaszem, z Boga się narodził" (1 J 5, 1).

Wracając do spotkania Jezusa z bogatym młodzieńcem (por. Mt 19, 16-22), należy zauważyć, że Chrystus wzywa młodzieńca, aby stał się doskonały, bowiem widzi, że w wymiarze duchowym jest on już zdolny do tego, aby z dziecka Bożego stać się synem Bożym. Dlatego całe to wydarzenie w kluczu inicjacyjnym należy odnieść do końcowego etapu katechumenatu, który podprowadza inicjowanego do początku etapu synowskiego. Bogaty młodzieniec doskonale wypełniał przykazania Dekalogu, czyli żył według zasad moralności Tory i proroków, ale zapewne już w duchu Kazania na górze. Jezus bowiem zaprasza go, aby poszedł za Nim, czyli wszedł na konkretny etap d rogi (por. Mk 10,17; 32), na którym był sam Jezus, a to wydarzenie ma miejsce tuż przed trzecią zapowiedzią Jego męki, śmierci i zmartwychwstania (por. Mk 10, 32-34). Pod wzglę-

13 Origenes, Commentariorum in Matthaeum series I, 15, 6, 23-31, Leipzig 1935, s. 362 (Griechischen Christlichen Schriftsteller, 40), ), przekł. pol.: Orygenes, Komentarz do Ewangelii św. Mateusza, tłum. K. Agustyniak, Kraków 1998, s. 236 (Źródła Myśli Teologicznej, 10). 
dem geograficznym jest to droga od Cezarei Filipowej do Jerozolimy. Natomiast w wymiarze inicjacyjnym droga symbolizuje tu rozwój wiary, począwszy od wyznania, że Jezus jest Mesjaszem (por. Mk 8, 27-29), a skończywszy na wyznaniu, że Jezus jest Synem Bożym (por. Mk 15, 39). $\mathrm{Na}$ tę drogę wiary Jezus chce wprowadzić człowieka, który upadł przed Nim na kolana. Ważny jest konkretny etap tej drogi, a jak już wspomnieliśmy, dzieje się to tuż przed wydarzeniem paschalnym Jezusa ${ }^{14}$.

Klemens Aleksandryjski tak komentuje wezwanie, które Jezus skierował do bogatego młodzieńca:

„Sprzedaj, co masz”. Co to znaczy? Nie żąda tu Zbawiciel, jak niektórzy zbyt pochopnie sądzą, aby porzucić posiadane mienie i wyrzec się majętności, ale poleca wyrwać z duszy powszechnie przyjęty sąd o bogactwach, przywiązanie do nich, nadmierną chciwość, niepokój o nie i namiętność, troski - ciernie życia, które zagłuszają nasienie wieczności ${ }^{15}$.

Do tej pory ewangeliczne wezwania dotyczące miłosierdzia, które analizowaliśmy, dotyczyły dzielenia się z ubogimi częścią majątku, który komuś zbywa. Natomiast tutaj Jezus domaga się sprzedaży całego kapitału i rozdania wszystkiego ubogim. Klemens Aleksandryjski uważa, że nie chodzi tu jednak o całkowitą rezygnację z posiadania, z czego byli znani w starożytności przede wszystkim radykalnie nastawieni nauczyciele greccy (cynicy $)^{16}$. Nie jest to również moment $\mathrm{w}$ rozwoju wiary, o którym mówią Dzieje Apostolskie (por. Dz 4, 34-35), kiedy to pierwsi chrześcijanie przekazywali cały swój majątek na rzecz wspólnoty, co wyrażało ich wiarę w Jezusa jako Syna Boga. Słowa, które Jezus kieruje do bogatego młodzieńca, są wezwaniem do wolności od posiadania, co Klemens rozumie jako wolność od przywiązania do dóbr materialnych, od niepokoju i troski o nie.

Jak jednak zaznacza ewangelista, bogaty młodzieniec nie dojrzał do takiej wolności, dlatego „odszedł zasmucony” (Mt 19, 22). W konsekwen-

14 Por. S. Haręzga, Jezus i Jego uczniowie. Model chrześcijańskiej formacji w Ewangelii wedtug św. Marka, Lublin 2006, s. 258-263.

15 Clemens Alexandrinus, Quis dives salvetur?, 11, 1-2, dz.cyt., s. 126-128; Klemens Aleksandryjski, Czy człowiek bogaty może być zbawiony, dz. cyt., s. 13.

16 Por. C. S. Keener, Komentarz historyczno-kulturowy do Nowego Testamentu, red. nauk. wyd. pol. K. Bardski, W. Chrostowski, przekł. Z. Kościuk, Warszawa 2000, s. 104. 
cji Jezus mówi o trudnościach, jakie bogaty napotyka, usiłując wejść do królestwa niebieskiego, używając obrazu wielbłąda przeciskającego się przez ucho igielne (por. Mt 19, 23-26). Reakcją uczniów na te słowa jest pytanie: „Któż więc może być zbawiony?” (Mt 19, 25). O jakie zbawienie, czyli uwolnienie, tutaj chodzi? Z kontekstu wynika, że pytanie dotyczy możliwości uwolnienia od przywiązania do posiadania poprzez jednorazowy akt sprzedaży majątku i obdarowania pieniędzmi ubogich. Kto spełni taki czyn, doświadczy zbawienia jako mesjańskiego uwolnienia. Z reakcji uczniów wynika, że egzystencjalne zbawienie mesjańskie, o którym Jezus tutaj mówi, nie jest ani łatwe, ani trudne; bowiem ono jest niemożliwe do osiągnięcia przez człowieka, odwołującego się czy to do moralności naturalnej, czy nawet moralności Tory i proroków ${ }^{17}$.

Pisze o tym Klemens Aleksandryjski, gdy komentuje odpowiedźJezusa na powyższe pytanie uczniów:

Pan zaś odpowiada: „Co niemożliwe jest u ludzi, możliwe jest u Boga”. I te także słowa są pełne wielkiej mądrości: człowiek o własnych siłach nie może uwolnić się od namiętności ani zdobyć pokoju ducha, choćby się trudził i starał; jeśli jednak okaże, że bardzo pragnie i gorliwie zabiega, Bóg udzieli mu tego daru przez użyczenie swojej mocy ${ }^{18}$.

Autor podkreśla pierwszeństwo łaski Bożej w doświadczeniu uwolnienia od namiętności (w tym wypadku od przywiązania do posiadania) i jednocześnie zaznacza, że człowiek powinien być aktywny w dążeniu do tego celu.

Katechumenat jest procesem, który rozpoczyna się w Ewangelii od powołania pierwszych uczniów. Natomiast spotkanie Jezusa z bogatym młodzieńcem ma miejsce tuż przed trzecią zapowiedzią Jego męki, śmierci i zmartwychwstania, czyli jest blisko paschalnego wydarzenia, które wprowadza inicjowanego w tajemnicę Jezusa jako Syna Boga, kończąc etap katechumenalny, a rozpoczynając etap synowski. Począwszy od powoła-

17 Por. B. Górka, Praxis w oparciu o Mk 10,17-31 i paralele, w: : B. Górka, Chrześcijaństwo pierwotne jako system religijny, dz.cyt., s. 55.

${ }_{18}$ Clemens Alexandrinus, Quis dives salvetur?, 21, 1-2, dz.cyt., s. 156-158; Klemens Aleksandryjski, Czy człowiek bogaty może być zbawiony, dz. cyt., s. 26. 
nia pierwszych uczniów, aż do spotkania z bogatym młodzieńcem, katechumen dojrzewa do doświadczenia pełnej wolności w Jezusie.

\section{Miłość nieprzyjaciół}

Piątym etapem rozwoju postawy miłosierdzia jest miłość nieprzyjaciół (por. Mt 5, 43-48, Łk 6, 27-38). Jezus twierdzi, iż ten, kto tak postępuje, staje się synem Ojca niebieskiego. Ewangeliści - zarówno Mateusz, jak i Łukasz - umieszczają tekst nauczania Jezusa o miłości nieprzyjaciół w kontekście błogosławieństw, wyraźnie wiążąc je z ostatnim, dotyczącym prześladowanych. Choć mowa tu o miłości, a nie o miłosierdziu, to jednak przesłanie tego ewangelicznego wezwania ściśle wiąże się z pojęciem miłosierdzia, które już Tertulian rozumiał jako lekarstwo na przejawy $z_{ł a}{ }^{19}$. Miłość nieprzyjaciół w sytuacji, kiedy uczniowie Jezusa doświadczają prześladowań ze względu na swego Pana, jawi się jako najdoskonalsza forma miłosierdzia czynionego poza ich wspólnotą. Dlatego Jezus, wzywając do takiej postawy, mówi: „Bądźcie więc wy doskonali, jak doskonały jest Ojciec wasz niebieski” (Mt 5, 48), a w wersji św. Łukasza: „Bądźcie miłosierni, jak Ojciec wasz jest miłosierny" (Łk 6, 36).

Jezus na początku nauczania o miłości nieprzyjaciół ukazuje cel tej miłości, a jest nim zapobieżenie eskalacji zła i uzdrowienie duchowe tych, którzy czynią zło (por. Mt 5, 38-39). Starotestamentowa zasada oddawania złem za zło jest zmieniona na nową: „Nikomu złem za zło nie odpłacajcie" (Rz 12,17). Zaniechanie oddawania złem za zło sprawia, że ono się nie rozwija. Bowiem człowiek, który ulega pragnieniu zemsty, tak naprawdę ulega złu i podwójnie jest zraniony, najpierw przez złego człowieka, a następnie przez zło duchowe, które dopuszcza do siebie, kiedy dokonuje zemsty. Dlatego św. Paweł mówi: „Nie daj się zwyciężyć złu, ale zło dobrem zwyciężaj” (Rz 12, 21). Samo zaniechanie odwetu jest formą obrony przed złem duchowym, aby ono nie zakorzeniło się w człowieku, który doznał jakiejkolwiek krzywdy od innych. Jezus, a za Nim św. Paweł zachęcają do podjęcia walki o człowieka, który czyni zło.

19 L. Mateja, Oblicza miłosierdzia..., dz. cyt., s. 278. 
Tak o tym pisze Ambroży z Mediolanu:

Czy przez to nie ucisza się gwałtowności drugiego i nie uspakaja się jego gniewu? Czy swą cierpliwością nie uderzasz tego, który cię uderzył, aby go skruszyć? Przez to i wyrządzoną ci krzywdę odpierasz i o zjednanie miłości się starasz? Często się zdarza, iż przez to szczególniej ją się zdobywa, jeśli za zuchwalstwo odpłaca się cierpliwością, a za zniewagę odpowiada się uprzejmością ${ }^{20}$.

Autor podkreśla rolę cierpliwości wobec agresora, poprzez którą można odeprzeć atak i zjednać sobie przeciwnika.

Zasada zwyciężania zła dobrem dotyczy nie tylko sytuacji, w których uczeń Chrystusa doświadcza cierpień fizycznych i upokorzeń, ale także takich, kiedy zabierane są mu dobra materialne oraz czas i jest on zmuszany do podjęcia niesprawiedliwego trudu czy też pod jakąkolwiek presją jest nakłaniany do spełnienia próśb (por. Mt 5, 40-42). Wszystkie te pouczenia dotyczą sytuacji, kiedy uczniowie są prześladowani. Przy czym Jezus niejako stopniuje poziom tej wrogości od największej do najmniejszej. Bowiem najtrudniej jest znieść przyjmowanie upokorzeń i cierpień fizycznych (por. Mt 5, 39), a następnie niesprawiedliwości dotyczącej dóbr materialnych (por. Mt 5, 40). W dalszej kolejności Jezus wzywa do umiejętności przyjęcia sytuacji, kiedy ktoś jest zmuszony do poświęcenia czasu i trudu fizycznego (por. Mt 5, 41).

Wreszcie następują słowa: „daj temu, kto cię prosi” (Mt 5, 42a), które należy odczytać także w kontekście prześladowań. Chodzi tu więc zapewne o spełnienie próśb kierowanych pod jakąkolwiek presją, dotyczy to także udzielania pożyczek w podobnych sytuacjach. O tym, że ostatnie cytowane wezwanie Jezusa dotyczy również sytuacji związanych z prześladowaniami, świadczą paralelne słowa zapisane przez św. Łukasza (por. Łk 6, 30-35). Ewangelista Łukasz nie pisze jak Mateusz: „pożycza od ciebie” (Mt 5, 42b), ale „bierze twoje” (Łk 6, 30b), jeśli zatem ta pożyczka jest wymuszona, to zapewne wcześniejsze słowa: „dawaj każdemu, kto cię prosi” (Łk 6, 30a) są kierowane w podobnych okolicznościach. Przy analizie powyższych fragmentów Ewangelii nie można zapominać o innej prawdzie biblijnej, mówiącej o tym, że w normalnych okolicznościach, kiedy nie doświad-

20 Ambrosius, Expositio Evangelii secundum Lucam, 5, 76, dz. cyt., s. 160; Ambroży, Wykład Ewangelii według św. Łukasza, dz. cyt., s. 192. 
cza się prześladowań, jałmużny należy udzielać tylko osobom sprawiedliwym (por. Tb 4, 7).

Najstarsza tradycja Kościoła podkreśla, że w dziedzinie miłosierdzia należy połączyć ze sobą dwie na pozór przeciwstawne cnoty: hojność i roztropność, o czym świadczy fragment z Didache:

Daj każdemu, kto cię prosi, i zwrotu nie dopominaj, ponieważ Ojciec chce, żebyśmy z wszystkimi dzielili się własnymi darami. Szczęśliwy ten, kto daje według przykazania, gdyż nic mu nie można zarzucić. Biada temu, kto bierze! Jeżeli bowiem bierze dlatego, że potrzebuje, nic mu nie można zarzucić; jeśli jednak nie potrzebuje, zda sprawę z tego, dlaczego wziął i po co. Wsadzony do piwnicy, odpowie za wszystkie swoje czyny i nie wyjdzie stamtąd, aż ostatni grosz zwróci. Powiedziano jeszcze na ten temat: „Niech twoja jałmużna przesiąknie potem rąk twoich, aż będziesz wiedział, komu dajesz ${ }^{21}$.

Cytowany fragment rozpoczyna się od wezwania do hojności wobec potrzebujących, a kończy radą, aby dobrze rozpoznać, komu się pomaga, co jest cechą roztropności. Jest w nim również zawarte mocne ostrzeżenie dla tych, którzy korzystają z miłosierdzia innych, aby nie nadużywali hojności darczyńców.

Motywacją uczniów Jezusa do okazywania miłosierdzia swoim nieprzyjaciołom są słowa: „miłujcie waszych nieprzyjaciół” (Mt 5, 44a). Według Antoniego Paciorka „miłość, o której tu mowa, nie jest sprawą emocji i sentymentu, ale polega na postawie życzliwości wyrażającej się w konkretnych czynach"22. Jezus zatem wzywa swoich uczniów nie tyle do współczucia swoim nieprzyjaciołom, którzy zarazili się złem, ile przede wszystkim do podjęcia ich leczenia poprzez okazanie im miłosierdzia. W związku z tym, że nieprzyjaciel zapadł na chorobę duchową, Jezus dodaje jeszcze jeden składnik leku, mówiąc: „módlcie się za tych, którzy was prześladują” (Mt 5, 44b). W wyrażeniu „módlcie się” kryje się podobna idea aktywności jak w poprzednim terminie „miłujcie”. Zatem ma to być nie jednorazowa modlitwa, ale nieustanna prośba skierowa-

${ }^{21}$ Didache, 1, 5-6, Paris 1978, s. 144-146 (Sources Chretiennes, 248); przekł. pol.: Nauka Dwunastu Apostołów, w: Ojcowie Apostolscy, tłum. A. Świderkówna, oprac. W. Myszor, Warszawa 1990, s. 57 (Pisma Starochrześcijańskich Pisarzy, 45).

22 A. Paciorek, Ewangelia według świętego Mateusza, rozdziały 1-13, cz. 1, Częstochowa 2005, s. 250. 
na do Ojca niebieskiego o uwolnienie od zła tych, którzy są narzędziami w ręku diabła.

Uczniowie Jezusa, którzy okazują miłosierdzie swoim nieprzyjaciołom, staną się synami Ojca, który jest w niebie (por. Mt 5, 45-48). Miłosierdzie jest tu porównane do słońca i deszczu, czyli do elementów, które decydują o życiu fizycznym na ziemi. Zatem miłosierdzie jest czymś równie istotnym dla życia duchowego. Bóg okazuje miłosierdzie wszystkim ludziom, tak jak daje im słońce i deszcz. Podobnie i uczniowie Jezusa mają okazywać miłosierdzie wszystkim, zarówno dobrym, jak i złym. W ten sposób będą się odróżniać od innych ludzi: celników i pogan, jak zapisał ewangelista Mateusz (por. Mt 5, 46-47), oraz grzeszników, jak twierdzi Łukasz (por. Łk 6, 32-34).

Ambroży z Mediolanu, komentując ten fragment Ewangelii, pisze:

Ma więc chrześcijanin dobry przykład, aby nie zadowalając się wykonaniem prawa natury, zaprawił ją życzliwością. Skoro bowiem wspólne jest wszystkim, również grzesznikom, odpłacać za miłość miłością, to jednak ten, kto dąży do czegoś wznioślejszego, winien szerzej miłość pojmować i kochać tych, którzy go nie miłująa23.

Według autora taka postawa uczniów Jezusa wykracza poza prawo naturalne, które jest dostępne dla wszystkich.

Z punktu widzenia rozwoju postawy miłosierdzia w kluczu inicjacyjnym miłość nieprzyjaciół sytuuje się na samym końcu etapu katechumenalnego, stanowiąc zarazem początek etapu synowskiego. Jezus podkreśla, że Jego uczeń z pozycji katechumena, czyli dziecka Bożego, dzięki miłości nieprzyjaciół stanie się synem Bożym (por. Mt 5, 44-45). Jezus zatem stopniowo podprowadza swoich uczniów do postawy miłosierdzia, które obejmuje również Jego prześladowców. Warunkiem koniecznym do miłowania nieprzyjaciół jest najpierw doświadczenie wolności od posiadania, gdyż tylko wtedy uczeń Jezusa będzie zdolny do oddania dóbr materialnych swoim prześladowcom, ale także godnego przyjęcia cierpień fizycznych i moralnych. Jeśli postawa wolności od posiadania jest krokiem

23 Ambrosius, Expositio Evangelii secundum Lucam, 5, 75, dz. cyt., s. 160; Ambroży, Wykład Ewangelii według św. Łukasza, dz.cyt., s. 191. 
w kierunku uczestniczenia w wydarzeniu paschalnym Jezusa, to miłość nieprzyjaciół jest już wejściem w to doświadczenie.

Miłość nieprzyjaciół, która ściśle wiąże się z przyjęciem prześladowań ze względu na Jezusa, jest adresowana jeszcze do katechumenów. Stanowi ona jednak już koniec drogi katechumenalnej, a zarazem jest początkiem drogi synowskiej. Potwierdzeniem tej tezy jest doświadczenie starożytnego Kościoła, kiedy to katechumeni oddawali życie za wiarę w Jezusa, a wtedy ich śmierć męczeńską traktowano jako chrzest krwi, który dawał im pewność życia wiecznego. Miłość nieprzyjaciół jest zatem zadana inicjowanym na końcu etapu katechumenalnego, wprowadzając ich w doświadczenie wiary w Jezusa jako Syna Boga.

\section{Miłość wzajemna}

Jezus w czasie ostatniej wieczerzy przekazał swym uczniom nowe przykazanie miłości wzajemnej (por. J 13, 34-35). Na czym polega nowość tego przykazania? Przykazanie miłości bliźniego było odniesione do samego siebie, bowiem miarą tej miłości jest człowiek. Natomiast nowe przykazanie miłości Jezus odnosi do siebie. Wzywa uczniów, aby miłowali się wzajemnie, tak jak On ich umiłował. Miarą tej miłości jest więc Jezus w tajemnicy swego Bóstwa. Realizacja tego przykazania w życiu ma być elementem rozpoznawania uczniów Jezusa, podobnie jak w przypadku miłości nieprzyjaciół, gdzie mieli odróżniać się swoją postawą od pogan. W wymiarze inicjacyjnym przykazanie miłości wzajemnej jest zadane tym, którzy doświadczają egzystencjalnej wiary w Jezusa jako Syna Boga. W starożytnym Kościele był to moment przyjęcia chrztu. Podobnie jak w przypadku miłości nieprzyjaciół nie ma tu mowy wprost o miłosierdziu, ale o miłości, która ma rozwijać się aż do oddania życia za przyjaciół swoich (por. J 15, 12-13). Zatem także i w tym przypadku można mówić o miłosierdziu jako formie miłości w konfrontacji ze złem. Choć ten etap postawy miłosierdzia wykracza poza wyznaczone $w$ artykule ramy inicjacji przedchrzcielnej, warto pokrótce ukazać go w celu zarysowania całości ewangelicznej drogi rozwoju postawy miłosierdzia. 
W II wieku Polikarp ze Smyrny wzywał ochrzczonych do miłości wzajemnej w następujący sposób:

\begin{abstract}
W tym zatem trwajcie i naśladujcie przykład Pana. Mocni i niezachwiani w wierze, miłujcie braci, kochajcie się wzajemnie, a zjednoczeni w prawdzie, uprzedzajcie jedni drugich w łagodności Pana, nikim nie pogardzajcie. Kiedy możecie czynić dobrze, nie zwlekajcie, bo ,jałmużna wyzwala od śmierci”, ,Wszyscy bądźcie poddani sobie nawzajem i zachowujcie się wśród pogan bez zarzutu, aby dzięki waszym dobrym uczynkom" i was samych chwalono i nie bluźniono z waszego powodu Panu. A biada temu, kto sprawia, że inni bluźnią Pańskiemu Imieniu. Uczcie zatem wszystkich mądrości, w jakiej i wy sami żyjecie ${ }^{24}$.
\end{abstract}

Według autora fundamentem miłości wzajemnej chrześcijan powinno być ich zjednoczenie w prawdzie, a jej przejawem łagodność i wzajemny szacunek. Jego zdaniem miłość wzajemna we wspólnocie Kościoła ma promieniować na zewnątrz poprzez dobre i sprawiedliwe czyny uczniów Jezusa. Polikarp ostrzega również, że brak takiej postawy chrześcijan może być powodem do bluźnierstw wobec Jezusa.

Jak już wspomnieliśmy, kresem rozwoju miłości wzajemnej jest oddanie życia za przyjaciół (por. J 15, 12-13). Warto w tym miejscu zaznaczyć, że jeśli początkiem rozwoju postawy miłosierdzia było pozyskiwanie sobie przyjaciół niegodziwą mamoną, to najdoskonalszą jej formą jest oddanie życia za przyjaciół. Miłość wzajemna i miłość nieprzyjaciół mają być znakami, po których rozpoznaje się uczniów Jezusa. Jednak różnica między nimi polega przede wszystkim na odmienności środowisk, w których są one wyrażane. Miłość wzajemna ma obejmować wszystkich we wspólnocie uczniów Jezusa, natomiast miłość nieprzyjaciół dotyczy tych, którzy pozostają poza nią.

Pełna realizacja przykazania miłości wzajemnej jest możliwa tylko dla tych, którzy doświadczają egzystencjalnej wiary w Jezusa jako Syna Boga, jednocząc się z Nim w Jego Bóstwie. Stąd doświadczeniem tych, którzy okazują sobie miłość wzajemną, jest wejście w proces przebóstwienia, o czym między innymi pisał Klemens Aleksandryjski: „Zaprawdę

24 Polycarpus, Epistula ad Philippenses, 10,1-3, Paris 1958, s. 216 (Sources Chretiennes, 10), przekł. pol.: Polikarp ze Smyrny, List do Kościoław Filippi, w: Ojcowie Apostolscy, tłum. A. Świderkówna, oprac. W. Myszor, Warszawa 1990, s. 100 (Pisma Starochrześcijańskich Pisarzy, 45). 
powiadam wam, Słowo stało się człowiekiem, abyś ty także nauczył się od człowieka, w jaki sposób będąc człowiekiem, możesz stać się Bogiem"25. Natomiast Augustyn, komentując przykazanie wzajemnej miłości, pisał: „Oni miłują nie jak ci, którzy grzeszą, ich miłość nie jest zwyczajną ludzką miłością. Lecz są bogami i wszyscy są synami Najwyższego i braćmi Jedynego Syna Bożego, a więc miłują się wzajemnie tą miłością, jaką umiłował ich Pan"26. Biskup Hippony podkreśla, że miłość wzajemna nie ma swego źródła w naturze człowieka, lecz wypływa wprost z miłości Boga. Proces rozwoju miłosierdzia człowieka rozpoczyna się więc od filantropii, która jest wyrazem ludzkiej miłości. Natomiast dzięki wtajemniczeniu w osobę Jezusa Chrystusa człowiek stopniowo rozwija swoją umiejętność okazywania miłosierdzia, aż po doświadczenie udziału w miłości samego Boga, wyrażającej się we wzajemnej miłości we wspólnocie Kościoła.

\section{Podsumowanie}

Podsumowując, należy stwierdzić, że filantropia, czyli miłosierdzie czynione ze względu na miłość do człowieka, jest postawą charakterystyczną dla tych, którzy w Kościele starożytnym byli na etapie wstępnym inicjacji chrzcielnej, zwanej przez Klemensa Aleksandryjskiego „zachętą". Drugi etap rozwoju postawy miłosierdzia jest związany z podejmowaniem uczynków miłosierdzia ze względu na Boga i cechował tych, którzy przeżywali etap prekatechumenalnego wtajemniczenia. Przy czym należy zaznaczyć, że podejmowanie uczynków miłosierdzia ze względu na miłość do Boga zakłada również miłość do człowieka. Jest to bowiem kolejny etap rozwoju postawy miłosierdzia, który można porównać do drugiego piętra domu miłosierdzia, wznoszonego na fundamencie spra-

25 Clemens Alexandrinus, Protrepticus, 8, 4, Paris 1949, s. 63 (Sources Chretiennes, 2 bis), przekł. pol.: Klemens Aleksandryjski, Zachęta Greków, w: Apologie, tłum. J. Sołowaniuk, red. E. Stanula, Warszawa 1988, s. 123 (Pisma Starochrześcijańskich Pisarzy, 44).

26 Augustinus Hipponesis, In Johannis Evangelium tractatus CXXIV, 65, 1, Turnholti 1954, s. 491 Corpus Cristianorum Series Latina, 36), przekł. pol.: św. Augustyn, Homilie na Ewangelie i Pierwszy List św. Jana, tłum. W. Szołdrski, Warszawa 1977, s. 124 (Pisma Starochrześcijańskich Pisarzy, 15/2). 
wiedliwości. Podobnie kolejne etapy rozwoju postawy miłosierdzia bazują na wcześniejszych.

Trzeci etap rozwoju postawy miłosierdzia dotyczy doskonalenia umiejętności wzruszenia się miłosierdziem wobec cierpiącego człowieka. Ten etap wiąże się z początkiem rozwoju egzystencjalnej wiary inicjowanego w Jezusa jako Mesjasza, a zatem w starożytności był to moment, kiedy wchodził on na drogę katechumenatu. Znakiem zakończenia procesu katechumenalnego oczyszczenia było osiągnięcie wolności od posiadania dóbr ziemskich. Natomiast praktykowanie miłości nieprzyjaciół wprowadzało inicjowanego $\mathrm{w}$ doświadczenie wiary w Jezusa jako Syna Boga, wtedy to wtajemniczany z dziecka Bożego stawał się synem Bożym. Praktykowanie miłości wzajemnej jest ostatnim ewangelicznym etapem rozwoju postawy miłosierdzia, charakterystycznym dla tych, którzy egzystencjalnie doświadczają wiary w Bóstwo Jezusa, co w starożytności wiązało się z momentem przyjęcia chrztu. 


\section{Summary}

\section{Ewangeliczne etapy rozwoju postawy miłosierdzia w świetle wybranych fragmentów pism ojców Kościoła}

W artykule przedstawiono zarys ewangelicznych etapów rozwoju postawy miłosierdzia w wymiarze materialnym w świetle wybranych fragmentów pism ojców Kościoła, wiążąc je z etapami inicjacji przedchrzcielnej w starożytnym Kościele. W tym celu wykorzystano metodę inicjacyjnego odczytania tekstów Nowego Testamentu. Dzięki tej metodzie wyodrębniono na etapie wstępnym inicjacji miłosierdzie podejmowane ze względu na dobro człowieka, zwane filantropią. Na etapie preakatechumenalnym inicjowany był już wzywany, aby podejmować czyny miłosierdzia ze względu na Boga. Celem etapu katechumenalnego było natomiast doskonalenie wrażliwości miłosierdzia. Pod koniec tego etapu wzywano katechumena do wolności wobec dóbr materialnych, którymi w większym stopniu niż poprzednio miał dzielić się z ubogimi. Katechumenat kończył się doskonaleniem postawy wyrażonej w miłości nieprzyjaciół, był to jednocześnie moment przyjęcia chrztu i wejścia w doświadczenie realizacji przykazania miłości wzajemnej.

Słowa kluczowe: inicjacja, katechumenat, chrzest, miłosierdzie, miłość

\section{Evangelical Stages of the Development of Mercy's Attitude in the View of Selected Extracts from Scripts of the Fathers of the Church}

In the article there is shown an outline of evangelical stages of the Church's development of mercy's attitudes in the material dimension in view of selected extracts from scripts of the Fathers of the Church, matching them with pre-baptism initiation in the ancient Church. For this purpose, an initiation method was used to interpret the text of the New Testament. Thanks to this method, mercy was extracted at the entry period of pre-initiation. Works of Mercy that is taken for the good of a human person called philanthropy. At the precatechumenate period the initiated one was called to perform merciful acts because of God whereas the target of catechumenate period was to improve one sensitivity towards mercy. At the end of this period, a catechumen was called to be free with material goods, which were to be shared with the poor more than before. The catechumenate ended with the improvement of the attitude expressed by love to enemies. At the same time it was the moment of the baptism and entrance into the experience of the fulfilment of precept of mutual love.

Keywords: initiation, catechumenate, baptism, mercy, love 


\section{Bibliografia}

Ambrosius, Expositio Evangelii secundum Lucam, Turnholti 1957 (Corpus Cristianorum Series Latina, 14), przekł. pol.: Ambroży, Wykład Ewangelii według św. Łukasza, tłum. W. Szołdrski, Warszawa 1977 (Pisma Starochrześcijańskich Pisarzy, 16).

Augustinus Hipponesis, De civitate Dei, Turnholti 1955 (Corpus Cristianorum Series Latina, 47), przekł. pol.: Augustyn z Hippony, O Państwie Bożym, tłum. W. Kubiak, Kęty 1998.

Augustinus Hipponesis, In Johannis Evangelium tractatus CXXIV, Turnholti 1954 (Corpus Cristianorum Series Latina, 36), przekł. pol.: św. Augustyn, Homilie na Ewangelię i Pierwszy Listśw. Jana, tłum. W. Szołdrski, Warszawa 1977 (Pisma Starochrześcijańskich Pisarzy, 15/2).

Clemens Alexandrinus, Protrepticus, Paris 1949 (Sources Chretiennes, 2 bis), przekł. pol.: Klemens Aleksandryjski, Zachęta Greków, w: Apologie, tłum. J. Sołowaniuk, red. E. Stanula, Warszawa 1988 (Pisma Starochrześcijańskich Pisarzy, 44).

Clemens Alexandrinus, Quis dives salvetur?, Paris 2011 (Sources Chretiennes, 537), przekł. pol.: Klemens Aleksandryjski, Czy człowiek bogaty może być zbawiony, tłum. J. Czuj, Warszawa 1953.

Didache, Paris 1978 (Sources Chretiennes, 248), przekł. pol.: Nauka Dwunastu Apostołów, w: Ojcowie Apostolscy, tłum. A. Świderkówna, oprac. W. Myszor, Warszawa 1990 (Pisma Starochrześcijańskich Pisarzy, 45).

Górka B., Ewolucyjny charakter chrześcijańskiej moralności, w: B. Górka, Chrześcijaństwo pierwotne jako system religijny, Kraków 2011, s. 17-34.

Górka B., Podejście inicjacyjne do Ewangelii Jana, w: B. Górka, Hermeneutyka inicjacji wczesnochrześcijańskiej, Kraków 2007, s. 35-65.

Górka B., Praxis w oparciu o Mk 10, 17-31 i paralele, w: B. Górka, Chrześcijaństwo pierwotne jako system religijny, Kraków 2011, s. 13-26.

Haręzga S., Jezus i Jego uczniowie. Model chrześcijańskiej formacji w Ewangelii według św. Marka, Lublin 2006.

Keener C. S., Komentarz historyczno-kulturowy do Nowego Testamentu, red. nauk. wyd. pol. K. Bardski, W. Chrostowski, przekł. Z. Kościuk, Warszawa 2000.

Kudasiewicz J., Miłosierdzie w słowach i czynach Jezusa, w: Dives in misericordia. Tekst $i$ komentarz, Kraków 1981, s. 98-110.

Łucarz S., Disciplina arcani w „Kobiercach” Klemensa Aleksandryjskiego, w: Disciplina arcani w chrześcijaństwie, red. W. Gajewski, B. Górka, Kraków 2015, s. 75-91.

Machniak J., Miłosierdzie a filantropia, w: Wspótczesne oblicza miłosierdzia, red. L. Mateja, Kraków 2007, s. 73-86.

Mateja L., Bóg mówi do ciebie: zaufaj Mi. Biblijna szkoła ufności i miłosierdzia, Kraków 2017.

Mateja L., Oblicza miłosierdzia. Historyczne uwarunkowania rozwoju doktryny o miłosierdziu. Studium dzieł Tertuliana i świętego Cypriana, Kraków 2003.

Origenes, Commentariorum in Matthaeum series I, Leipzig 1935 (Griechischen Christlichen Schriftsteller, 40), przekł. pol.: Orygenes, Komentarz do Ewangelii św. Mateusza, tłum. K. Agustyniak, Kraków 1998 (Źródła Myśli Teologicznej, 10). 
Origenes, Commentariorum in Matthaeum series II, Leipzig 1933 (Griechischen Christlichen Schriftsteller, 38), przekł. pol:: Orygenes, Komentarzdo Ewangeliiśw. Mateusza, cz. 2, tłum. K. Agustyniak, Kraków 2002 (Źródła Myśli Teologicznej, 25).

Paciorek A., Ewangelia wedlug świętego Mateusza, rozdziały 1-13, cz. 1, Częstochowa 2005. Polycarpus, Epistula ad Philippenses, Paris 1958 (Sources Chretiennes, 10), przekł. pol.: Polikarp ze Smyrny, List do Kościoła w Filippi, w: Ojcowie Apostolscy, tłum. A. Świderkówna, oprac. W. Myszor, Warszawa 1990 (Pisma Starochrześcijańskich Pisarzy, 45).

Romaniuk K., Biblijny traktat o miłosierdziu, Ząbki 1994. 